\title{
MODIFICATION OF ASPHALT MIXES USING WHITE CEMENT DUST AND IRON FILINGS AS A FILLER
}

Scientific paper

Ibrahim Khliefat

(Received: 25 August 2020; accepted: 9 November 2020)

Department of Civil Engineering, Faculty of Engineering, Al-Balqa Applied University, Al-Salt, Jordan, Ph.D., Assistant Professor

Corresponding Author: khliefat@bau.edu.jo

\section{Majed Msallam}

Department of Civil Engineering, Faculty of Engineering Technology, Al-Balqa Applied University, Amman, Jordan, Ph.D., C.E. Associate Professor

\begin{abstract}
The possibility of using white cement dust and iron filings as fillers to modify asphalt mix properties was investigated. Numerous aggregate tests were conducted, including sieve analysis, specific gravity, absorption, and abrasion tests. Several bitumen tests were also conducted, including penetration, softening point, ductility, flash point, and specific gravity tests. Marshall properties were used to evaluate the physical performance of the mixtures. The construction of pavements with iron filings in hot asphalt mixtures is not recommended, but white cement dust powder or limestone powder can be beneficial. A $5 \%$ content was observed to be the best white cement dust content. There is no clear relationship between air voids and the percentages of white cement dust and iron filings, as the curve fluctuates. The use of white cement dust as a filler always exhibits better results; therefore, using white cement dust widely is recommended over using iron filings.
\end{abstract}

Keywords: Asphalt; fillers; iron filings; white cement dust. 


\section{INTRODUCTION}

Different types of waste materials are produced by factories. These include oils, scrap, slag, fly ash, metal, acids, rubber, stone pieces, and powders used in their main production [1]. Generally, waste materials can be divided into two main forms: hazardous and nonhazardous [2]. White cement dust (WCD), which is also identified as cement kiln dust (CKD), is formed as a by-product material in cement factories during cement production [3-5]. The gases released by cement kilns push the white cement dust to evaporate the electrostatic precipitators by fabric filters. Several factors, such as raw materials, methods, and facilities of dust collection, fuel combustion, and feeding process influence the chemical and physical properties of CKD [6]. The general properties of CKD are identical to those of Portland cement.

Highway authorities are concerned with providing smooth, economical, and safe pavements to carry the expected loads. In this regard, the influence of iron filings (IF) and WCD as part of the fine aggregate in asphalt concrete mixtures is examined in this study. The impact of IF and WCD on the mechanical properties of asphalt concrete mixtures is also assessed. The goal is to investigate the possibility of using WCD and IF as fillers to modify asphalt mix properties. The secondary aim of this study is to evaluate the use of WCD and IF as fillers in hot mix asphalts. Specifically, this study aims to:

- examine the impact of IF and WCD on asphalt mix properties,

- implement a series of sample mixes composed of different WCD and IF percentages and aggregate gradations to achieve Marshal stability, and

- assess the addition percentage of IF or WCD in hot mix asphalts.

\section{LITERATURE REVIEW}

\subsection{Pavement structure}

The flexibility of hot mix asphalt pavements is fully reliant on the deflects or flexes under loading of the total pavement structure. Therefore, if the pavement structure is downwards against a particular layer, it will sustain a lower load. The asphalt course comprises a mixture of bituminous materials and mineral aggregates [7]. This mixture is adjusted as the upper course and is often developed on a base course owing to the surface course of the asphalt pavement structure. The binder course is a combination of the road base and the wearing course. Therefore, it reduces the stresses that affect the road base and the soil base. The selection of the aggregate mixture depends on the thickness of the layer (Figure 1).

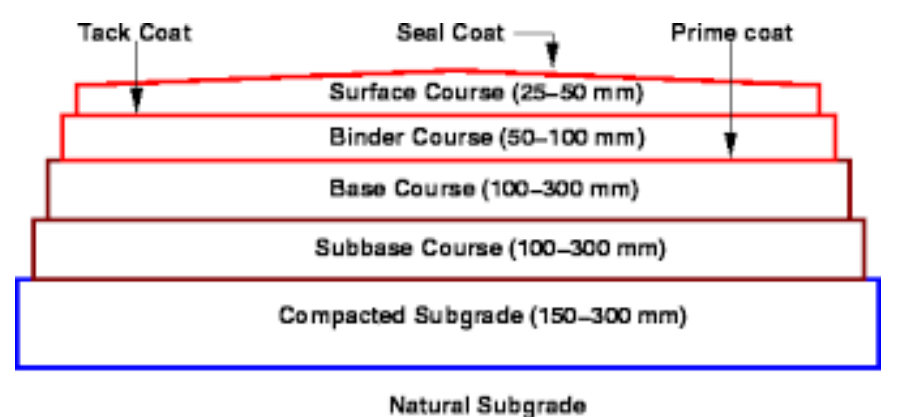

Figure 1 Pavement structure

\subsection{Hot mix asphalts}

Globally, hot mix asphalts are the most often used paving material, currently available with different names including plant mix, bituminous concrete, asphaltic concrete, and bituminous mix. It is a mixture of two primary aspects: asphalt binder and aggregates. Both fine and coarse materials are included in aggregates based on a combination of sand and size rock. The aggregates usually comprise $95 \%$ of the total mixture in terms of weight. They are combined with almost $5 \%$ asphalt binder when producing hot mix asphalt. In the presence of a group of specific materials, the location of the pavement is observed in the in situ soil. 


\subsection{Previous studies}

The use of different materials such as WCD and IF has been largely investigated by many researchers. Similarly, the effect and the study of the behavior of many mechanical and physical asphalt mix properties have also been investigated and documented. Othman [8] investigated the effect of using WCD as a filler at different percentages $(0 \%-5 \%)$. The study revealed that the use of WCD is significant for values of the Marshall stability and unit weight of the mix, while the effect on other properties such as air voids (AV) was not important. Voids in the mineral aggregates (VMA) and flow were slightly reduced. In general, the WCD percentage increases the stability and the unit weight, whereas the $\mathrm{AV}, \mathrm{VMA}$, and flow decreased.

Choi et al. [9] studied the impact of WCD on asphalt cement performance in hot mix asphalt. Their results indicated that the use of cement in asphalt mixes as a filler prevents stripping of the binder in dried aggregates. In addition, it enhances the coating of wet aggregates with bitumen. Therefore, improving the curing and strength of Cold Bituminous Emulsion Mixture (CBEM) using by-products or waste materials is examined in this study. Substantial improvements in CBEM characteristics were observed by use of some of these fillers. Asphalt concrete mixtures were produced based on the outcomes of Marshall tests on mix design, and lower flow, higher Marshall stability, and fewer voids in the total mix were observed in comparison with lime stone powder fillers and ordinary Portland cements [10]. Sorvig and Thompson [11] have shown dramatic water resistance and a large modulus of resilience in hot mix asphalt when WCD is used.

\subsection{Theory}

Several different elements comprise asphalt concrete-asphalt cement, coarse aggregates, filler, and fine aggregates-based on specific needs. Mineral fillers occupy the gap space between the pores and coarse aggregate particles throughout the aggregate particles based on inert material passing through a \#200 sieve [9]. In hot asphalt concrete mixtures, different local waste materials have been successfully used as mineral fillers to replace limestone powder and ordinary Portland cement. The impact of different types of content and fillers on hot asphalt concrete mixtures has been experimentally examined [12-15]. The impact of mineral filler has been evaluated through several experiments on asphalt mixes. From the outcomes of Marshall tests, it has been concluded that IF and WCD based on curing time are at their maximum levels in a mix design of hot asphalt concrete mixture.

\subsection{Methods of mix design}

During the past few decades, the Hveem method, the Marshall method of mix design, and the Superpave method of mix design and examination have been widely used as Hot Mix Asphalt (HMA) mix design methods. The Hveem and Marshall methods are primarily based on the HMA mix design. The Marshall and Hveem processes were improved by the Superpave system. Marshall [16] developed the Marshall method for HMA mix design in the 1940s; however, improvements and variations have been proposed by various organizations and engineers.

\subsection{Marshall method}

In the Marshall method, the resistance to plastic deformation is estimated for a specimen diametrically loaded at a deformation rate of $50 \mathrm{~mm} / \mathrm{min}$ by considering a compacted cylindrical bituminous mixture. The Marshall mix design method is based on two major aspects: stability-flow tests and density-void analysis. The maximum load carried by the specimen at a standard test temperature of $60^{\circ} \mathrm{C}$ defines the Marshall mix stability. During maximum loading, the test specimen undergoes a deformation flow. When employing the Marshall method, efforts are made to acquire optimum bitumen content for the aggregate mix type based on the anticipated traffic intensity [16]. 


\subsection{Determination of optimum bitumen content}

The average of three bitumen content values determines the optimum bitumen content based on the highest stability, median of allowed AV percentages, and highest bulk density value. These three values are obtained through Marshall graphs.

\subsection{Benefit of modified asphalt mixes}

The advantages of modified asphalts are identified by highway agencies to lessen the severity and amount of pavement distress as well as to augment service life. The primary advantage of using these high-performance asphalts is to enhance the mixture durability and rutting resistance and reduce thermal cracking. In addition, improved stripping resistance is provided by modified binders. To be precise, one of the reasonable expectations is the time period of pavement life, which is four to six years using a modified asphalt binder for pavement construction. However, extending the service life of pavements is another objective of highway agencies. The demands related to traffic become substantially more severe as the pavement ages. The AASHO Road Test was based on legal load limits of 73 and 280 pounds and, therefore, is still used for pavement design [17]. The load limit was increased to 80,000 pounds in 1982 , which may not seem like a huge increase, but an increase in the load level of 10 percent leads to 40 to 50 percent more pavement stress.

\section{METHODOLOGY}

\subsection{Laboratory testing}

The devices and equipment available at the University of Jordan laboratories were used to perform laboratory testing. These tests were divided into different stages, which commenced with the evaluation of properties of the materials used: IF, bitumen, aggregates, and WCF. Each aggregate type was measured through a sieve analysis to acquire the aggregate size grading. This was followed by aggregate blending for preparing asphalt mixes based on binder course gradation. Asphalt mixes were prepared using the optimum bitumen value with different percentages of IF and WCD. The properties of these modified mixes were evaluated using the Marshall test. Lastly, the laboratory outcomes were obtained.

\subsection{Apparatus}

\subsubsection{Breaking head}

Ductile iron, annealed steel tubing, cast steel, and upper and lower cylindrical segments of cast gray iron were included in the testing head. The lower segment was adjusted on a base, which comprises two perpendicular guide posts or rods. In the upper segment, guide sleeves lead the two segments mutually regardless of any loose motion or binding on the guide rods.

\subsubsection{Compression loading machine}

A screw jack used in the compression loading machine was adjusted in a testing frame under uniform vertical movement. A hydraulic or mechanical compression testing machine was also used in the study.

\subsubsection{Load measuring device}

A calibrated nominal ring dynamometer with a dial indicator was used to estimate the ring deflection for the applied loads. A minimum sensitivity of $50 \mathrm{~N}$ was required for the $20-\mathrm{kN}$ ring. The dial indicator was increased in segments of 0.0001 in or finer. The testing frame was attached to the ring dynamometer while the load was transmitted through the adapter to the breaking head. A load cell attached to a loaded formation recorder or computer replaced the ring dynamometer to provide sensitivity or capacity for fulfilling the requirements. High-stability mixes were based on a higher capacity ring dynamometer. These included dense gradation, stiff binders, crushed aggregates, and harsh gradation. 


\subsubsection{Flowmeter}

A gauge and guide sleeve were placed within the Marshall flowmeter. The guide sleeve was freely adjusted over the breaking head post, while the activating gauge pin was positioned inside the guide sleeve with minimum friction. These frictional resistance points were evaluated before the tests. The flowmeter gauge gradations were increased by 0.01 in or finer. Other devices, including a linear variable differential transducer or an indicator dial, were attached to a computer or a load deformation recorder rather than a flowmeter.

\subsection{Procedure}

Figures 2 and 3 show almost $1200 \mathrm{~g}$ of mineral filler and aggregates heated to 195 and $175^{\circ} \mathrm{C}$.

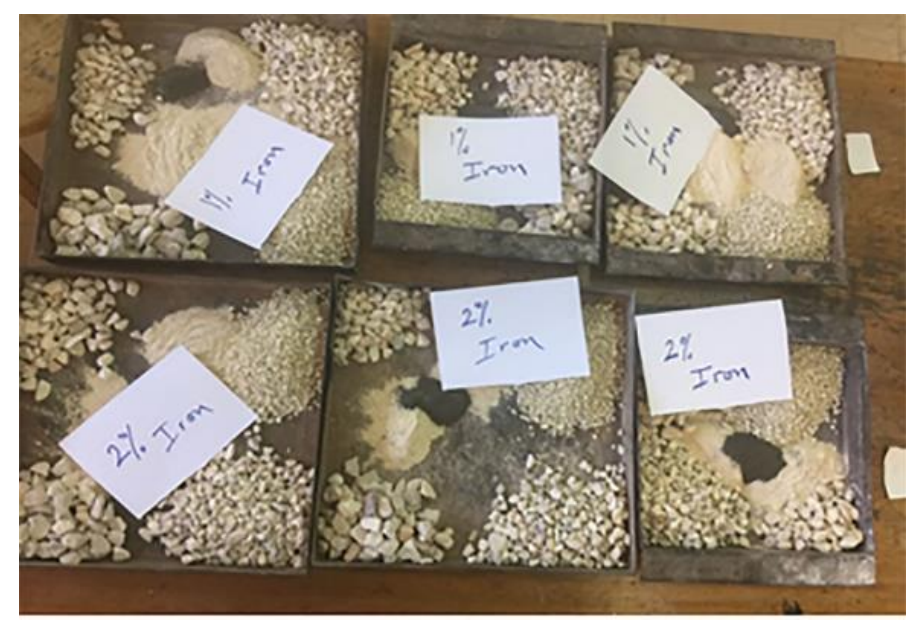

Figure 2 Preparation of samples

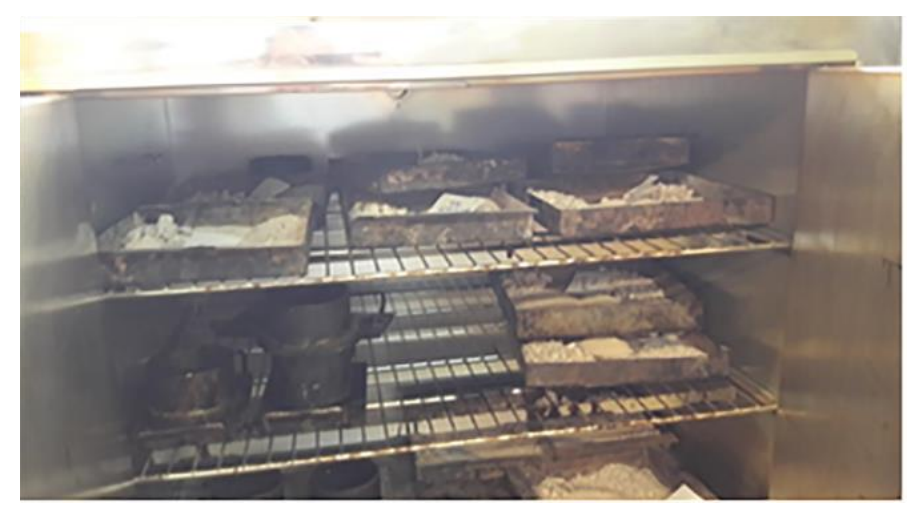

Figure 3 Heating the samples

The rammer and compaction mold assembly were preheated and cleaned to a temperature of up to $145^{\circ} \mathrm{C}$. The required quantity of bitumen trial percentage was added to the first heated aggregate and thoroughly mixed by using a hand mixing mixer trowel and a mechanical mixer (Figure 4). 


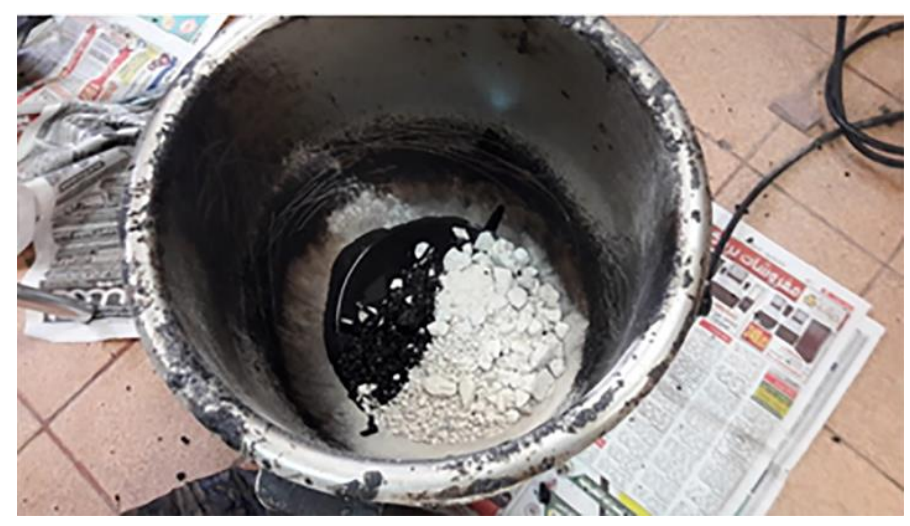

Figure 4 Preparation of samples to be mixed

Later, a temperature of $150-160^{\circ} \mathrm{C}$ was maintained to heat the mixture.

Figure 5 shows the thermostatically controlled water bath in which specimens were immersed in water for $40 \min$ at $60^{\circ} \mathrm{C}$.

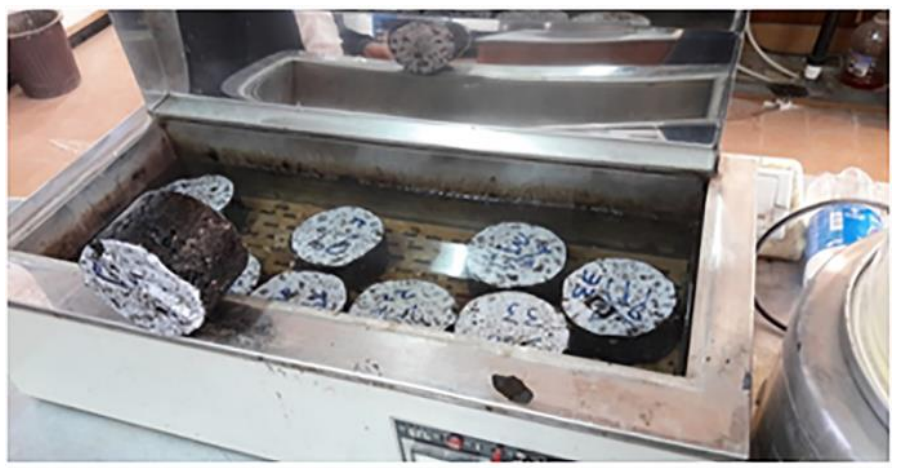

Figure 5 Putting samples in the water bath

\section{RESULTS AND DISCUSSION}

\subsection{Asphalt cement}

Recently, asphalt has been commonly used in pavement construction owing to its high engineering capabilities, including water resistance, elasticity, and adhesion. The physical and chemical properties of asphalt produced through crude oil refinement can be changed or enhanced by air blowing, additives, and blending. A petroleum asphalt grade, which is common in construction road projects in Jordan, was used in this study. The physical properties of asphalt were tested according to standard specifications and listed in Table 1.

Table 1 Physical properties of asphalt

\begin{tabular}{ccc}
\hline Property & Unit & Test result \\
\hline Penetration @ $25^{\circ} \mathrm{C}, 100 \mathrm{~g}, 5 \mathrm{~s}$ & $0.1 \mathrm{~mm}$ & 71 \\
Specific gravity @ $25^{\circ} \mathrm{C}$ & $-\bar{C}$ & 1.01 \\
Fire point & ${ }^{\circ} \mathrm{C}$ & 350 \\
Softening point $5{ }^{\circ} \mathrm{C}$ & ${ }^{\circ} \mathrm{C}$ & 50 \\
Ductility & $\mathrm{cm}$ & $100+$ \\
\hline
\end{tabular}




\subsection{Aggregates}

Figure 6 shows coarse aggregates based on abrasion resistance and a toughness requirement. Different sizes were used to separate the fine and coarse aggregates. The job mix limits of the gradation were fulfilled through the combined gradations of aggregates, which were predefined for dense paving wearing coarse mixtures. In this study, natural crushed course and fine aggregates from the roads in Amman city were investigated. A mechanical crusher was used to obtain crushed gravel. Identical controlled gradation was employed by the fine and coarse aggregates to fulfill the selected gradation (Table 2). The \#4 sieve was passed by a minimum of $45 \%$ of the aggregates, whereas a $4.76-\mathrm{mm}$ sieve retained $23 \%$ of fine and coarse aggregates. Table 3 lists the physical properties of these aggregates. A $5 \%$ absorption rate and a 3\% coarse aggregate were observed through fine aggregates.

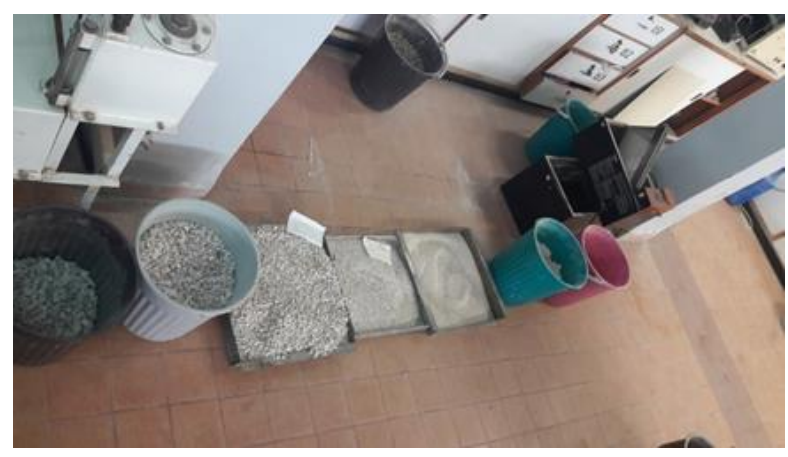

Figure 6 Aggregates

Table 2 Course and fine aggregate sieve analysis

\begin{tabular}{ccccc}
\hline $\begin{array}{c}\text { Sieve size } \\
{[\mathrm{mm}]}\end{array}$ & $\begin{array}{c}\text { Specification limits } \\
\text { (\% passing) }\end{array}$ & \% passing midpoint & \% retained & $\begin{array}{c}\% \text { cumulative } \\
\text { retained }\end{array}$ \\
\hline 19.5 & 100 & 100 & 0 & 0 \\
12.5 & $100-80$ & 90 & 10 & 10 \\
6.5 & $80-56$ & 68 & 22 & 32 \\
4.76 & $56-35$ & 45 & 23 & 55 \\
2.36 & $18-23$ & 30 & 15 & 70 \\
0.85 & $27-13$ & 20 & 10 & 80 \\
0.475 & $12-8$ & 10 & 10 & 90 \\
0.075 & $8-2$ & 5 & 5 & 95 \\
Pan & & & & 100 \\
\hline
\end{tabular}

Table 3 Physical properties of aggregates

\begin{tabular}{cccc}
\hline $\begin{array}{c}\text { Aggregate } \\
\text { type }\end{array}$ & $\begin{array}{c}\text { Specific gravity } \\
{\left[\mathrm{g} / \mathrm{cm}^{3}\right]}\end{array}$ & Los Angeles abrasion & Absorption \\
\hline Coarse & 2.58 & $32 \%$ & $3 \%$ \\
Fine & 2.55 & $33 \%$ & $5 \%$ \\
\hline
\end{tabular}

\subsection{Mineral filler}

The Asphalt Institute has defined mineral filler as a purely divided mineral product that passes through a \#200 sieve. The most commonly manufactured mineral filler is pulverized limestone, even though other usable products include dust, silica, hydrated lime, ordinary Portland cement, IF, and stone dust. Table 4 lists the physical properties of these mineral fillers. The findings indicate $90 \%$ passing a \#200 sieve for white cement and $60 \%$ passing a \#200 sieve for IF. 
Table 4 Physical properties of WCD and IF

\begin{tabular}{ccc}
\hline Type & Specific gravity & \% passing sieve \#200 \\
\hline White cement & 3.2 & $90 \%$ \\
IF & 2.8 & $60 \%$ \\
\hline
\end{tabular}

Subsequent monitoring revealed the tangential stiffness and fatigue resistance of HMA mixtures. Specifically, the WCD level of asphalt concrete $\mathrm{AC}(5.6 \%)$ resulted in a greater fatigue resistance as the strain rate increased from $77 \%$ to $84.33 \%$, and the IF level of AC (5.6\%) increased from $42.3 \%$ to $53.6 \%$. The results of WCD, IF, and mix between IF and WCD as a filler at $A C=5.6 \%$ are shown in Tables 5,6 , and 7 respectively.

Table 5 Results with WCD as filler at $A C=5.6 \%$

\begin{tabular}{cccccccc}
\hline $\begin{array}{c}\text { WCD } \\
\text { content } \\
{[\%]}\end{array}$ & $\begin{array}{c}\text { Densit } \\
\mathbf{y} \\
{\left[\mathrm{g} / \mathrm{cm}^{3}\right]}\end{array}$ & $\begin{array}{c}\text { Air } \\
\text { voids } \\
\mathbf{A V}[\%]\end{array}$ & $\begin{array}{c}\text { Voids in Mineral } \\
\text { Aggregates VMA } \\
{[\%]}\end{array}$ & $\begin{array}{c}\text { Voids Filled with } \\
\text { Asphalt VFA } \\
{[\%]}\end{array}$ & $\begin{array}{c}\text { Corrected } \\
\text { stability } \\
{[\mathrm{kg}]}\end{array}$ & $\begin{array}{c}\text { Flow } \\
{[0.1 \mathrm{in}]}\end{array}$ & $\begin{array}{c}\text { Stiffness } \\
\text { factor }\end{array}$ \\
\hline 0 & 2.121 & 6.774 & 18.66 & 64.382 & 957.328 & 12.667 & 77.2356 \\
1 & 2.145 & 5.707 & 17.729 & 67.892 & 1036.02 & 13.213 & 81.8312 \\
2 & 2.182 & 4.074 & 16.304 & 75.11 & 1092.13 & 13.537 & 80.382 \\
3 & 2.165 & 4.84 & 16.972 & 71.766 & 1135.87 & 15.48 & 86.3582 \\
4 & 2.180 & 4.196 & 16.41 & 74.482 & 1271.14 & 16.028 & 80.655 \\
5 & 2.206 & 3.046 & 15.407 & 80.312 & 1368.31 & 16.347 & 84.3361 \\
\hline
\end{tabular}

Table 6 Results with IF as filler at $A C=5.6 \%$

\begin{tabular}{cccccccc}
\hline $\begin{array}{c}\text { IF } \\
\text { content } \\
{[\%]}\end{array}$ & $\begin{array}{c}\text { Density } \\
{\left[\mathrm{g} / \mathrm{cm}^{3}\right]}\end{array}$ & $\begin{array}{c}\text { AV } \\
{[\%]}\end{array}$ & $\begin{array}{c}\text { VMA } \\
{[\%]}\end{array}$ & $\begin{array}{c}\text { VFA } \\
{[\%]}\end{array}$ & $\begin{array}{c}\text { Corrected } \\
\text { stability } \\
{[\mathrm{kg}]}\end{array}$ & $\begin{array}{c}\text { Flow } \\
{[0.1 \mathrm{in}]}\end{array}$ & $\begin{array}{c}\text { Stiffness } \\
\text { factor }\end{array}$ \\
\hline 0 & 2.121 & 6.774 & 18.66 & 64.382 & 957.328 & 12.667 & 77.23559 \\
1 & 2.13 & 6.376 & 18.313 & 65.256 & 779.394 & 15.231 & 51.16438 \\
2 & 2.117 & 6.931 & 18.797 & 63.212 & 738.214 & 17.055 & 45.51222 \\
3 & 2.117 & 6.946 & 18.81 & 63.075 & 546.271 & 12.579 & 43.54748 \\
4 & 2.129 & 6.42 & 18.351 & 65.132 & 589.302 & 15.537 & 38.87573 \\
5 & 2.125 & 6.602 & 18.51 & 64.454 & 801.316 & 14.717 & 54.30657 \\
\hline
\end{tabular}

Table 7 Results with a mixture of IF and WCD as filler at $A C=5.6 \%$

\begin{tabular}{ccccccccc}
\hline $\begin{array}{c}\text { WCD } \\
{[\%]}\end{array}$ & $\begin{array}{c}\text { IF } \\
{[\%]}\end{array}$ & $\begin{array}{c}\text { Density } \\
{\left[\mathrm{g}^{2} / \mathrm{cm}^{3}\right]}\end{array}$ & $\begin{array}{c}\text { AV } \\
{[\%]}\end{array}$ & $\begin{array}{c}\text { VMA } \\
{[\%]}\end{array}$ & $\begin{array}{c}\text { VFA } \\
{[\%]}\end{array}$ & $\begin{array}{c}\text { Corrected } \\
\text { stability } \\
{[\mathrm{kg}]}\end{array}$ & $\begin{array}{c}\text { Flow } \\
{[0.1 \mathrm{in}]}\end{array}$ & $\begin{array}{c}\text { Stiffness } \\
\text { factor }\end{array}$ \\
\hline 1 & 4 & 2.074 & 8.812 & 20.438 & 60.212 & 748.8 & 18.266 & 42.355 \\
2.5 & 2.5 & 2.197 & 3.415 & 15.729 & 78.309 & 783 & 17.853 & 44.583 \\
3 & 2 & 2.203 & 3.146 & 15.495 & 79.705 & 803 & 16.386 & 49.632 \\
4 & 1 & 2.209 & 2.889 & 15.27 & 81.26 & 972.9 & 16.533 & 59.546 \\
2 & 3 & 2.207 & 2.968 & 15.339 & 80.652 & 993.3 & 18.72 & 53.648 \\
\hline
\end{tabular}

\subsection{Comparison between WCD and IF percent}

Figure 7 displays the AV percentage results for different percentages of WCD and IF. As IF percentage varies, the AV percentage remains almost constant, but increasing the WCD percentage decreases the AV percentage. The actual density of the compacted mix defines the bulk density. The bulk density results are displayed in Figure 7 for different percentages of IF and WCD. Bulk density increased with increasing percentage of WCD, but it was almost constant with IF percentage. Flow occurs at the maximum load with a total deformation amount. The flow results for different percentages of IF and WCD are also shown in Figure 7. Flow increased with the increase in the

Khliefat, I, Msallam, M 
percentage of WCD, but it was not uniform with IF percentage, fluctuating in a zigzag pattern. Specimen failure occurred through the maximum load stability when applying a load at a constant rate of $50 \mathrm{~mm} / \mathrm{min}$. Figure 7 also displays the stability results for different percentages of WCD and IF. Stability increased with increasing percentage of WCD but started to increase at $3 \%$ IF. The VFA percentage results for different percentages of WCD and IF are also displayed in Figure 7. The minimum VFA content value is at $3 \% \mathrm{IF}$, whereas the VFA percentage increases with increasing percentage of WCD but not in a uniform manner. Finally, Figure 7 displays the VMA results for different percentages of WCD and IF. One can see that VMA decreases steadily as the percentage of WCD increases, but it is almost constant for different IF percentages.
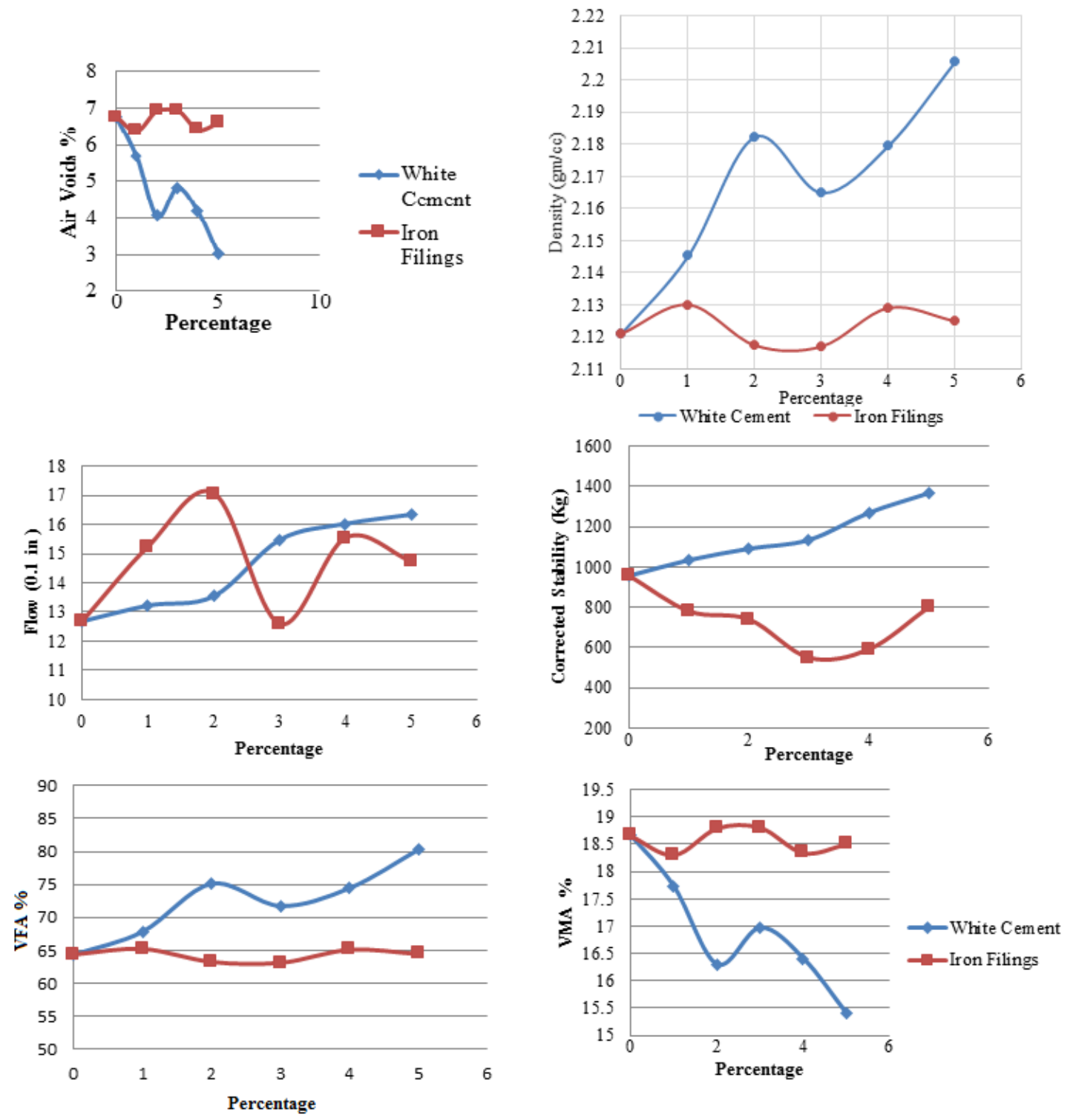

Figure 7 Comparison between WCD and IF percentages 


\section{CONCLUSIONS}

Increasing the WCD percentage increases the stability of Marshall mixes, with 5\% WCD providing the maximum stability. It is concluded that there is no clear relationship between AV and WCD and IF percentages, as the curves fluctuate non-uniformly. The VMA percentage was higher when using IF compared to WCD. The density was also higher when using WCD as a filler compared to IF. VFA was also examined, and the values were higher when using WCD as a filler.

The curves in figure 7 exhibit fluctuations, and no logical relationships were noticed; therefore, additional tests should be conducted in the future to better understand the relationships. The use of WCD as a filler always provides better results; therefore, its use instead of IF is recommended. Additional tests are recommended to check the results. The use of WCD as a filler is more convenient because of its availability in the marketplace. Mixed fillers with WCD and IF in asphalt mixes is also recommended. Further studies to conduct similar tests on other layers of asphalt mixes using different materials such as fiber are also advised. Future studies are recommended to investigate other gradations with WCD and IF and other forms of IF. Different ordinary Portland cement types, such as $7 \%$, can be used in future studies.

\section{References}

[1] Fadhil, T.H.; Jasim, S.S.; Aziz, K.E.; Ahmed A.S. 2017: Influence of using white cement kiln dust as mineral filler on hot asphalt concrete mixture properties, Anbar Journal of Engineering Sciences, 7 (2), pp. 148-157.

[2] Das, A. 2015: Structural design of asphalt pavements: principles and practices in various design guidelines, Transportation in Developing Economies, 1 (1), pp. 25-32. https://doi.org/10.1007/s40890-015-0004-3

[3] Liu, X.; Cui, Q.; Schwartz, C.W. 2018: Introduction of mechanistic-empirical pavement design into pavement carbon footprint analysis, International Journal of Pavement Engineering, 19 (9), pp. 763-771. https://doi.org/10.1080/10298436.2016.1205748

[4] Chong, D.; Wang, Y.; Dai, Z.; Chen, X.; Wang, D.; Oeser, M. 2018: Multiobjective optimization of asphalt pavement design and maintenance decisions based on sustainability principles and mechanistic-empirical pavement analysis, International Journal of Sustainable Transportation, 12 (6), pp. 461-472. https://doi.org/10.1080/15568318.2017.1392657

[5] Pinard, M.I.; Rolt, J.; Hongve, J.; Rattray, S.; Ribbens H.; Garner D.; Mukandila E. 2018: Development of Pavement and Geometric Design Standards for Low Volume Roads (Rural and Urban) In Zambia.

[6] Hall, K.D.; Schwartz, C.W. 2018: Development of Structural Design Guidelines for Porous Asphalt Pavement, Transportation Research Record: Journal of the Transportation Research Board, 2672 (40), pp. 197-206. https://doi.org/10.1177/0361198118758335

[7] AH AL-Saffar, N. 2013: The effect of filler type and content on hot asphalt concrete mixtures properties, ALRafdain Engineering Journal (AREJ), 21 (6), pp. 88-100. https://doi.org/10.33899/rengj.2013.82394

[8] Othman, A.M. 2009: Incorporation of white cement dust on rubber modified asphalt concrete mixtures, International journal of civil \&environmental engineering IJCEE, 9 (10), pp. 40-51.

[9] Choi, M.J.; Kim, Y.J.; Kim, H.J.; Lee, J.J. 2019: Performance evaluation of the use of tire-derived fuel fly ash as mineral filler in hot mix asphalt concrete, Journal of Traffic and Transportation Engineering (English Edition), 7(2), 249-258. https://doi.org/10.1016/j.jtte.2019.05.004

[10] Al-Busaltan, S. 2014: Investigating filler characteristics in upgrading cold bituminous emulsion mixtures, International Journal on Pavement Engineering \& Asphalt Technology, 15 (2), pp. 54-71.

[11] Sorvig, K.: Thompson J.W. 2018: Sustainable landscape construction: a guide to green building outdoors. Island Press.

[12] Arabani, M.; Tahami, S.A.; Taghipoor, M. 2017: Laboratory investigation of hot mix asphalt containing waste materials, Road Materials and Pavement Design, 18 (3), pp. 713-729. https://doi.org/10.1080/14680629.2016.1189349

[13] Mistry, R.; Roy, T.K. 2016: Effect of using fly ash as alternative filler in hot mix asphalt, Perspectives in Science, 8, pp. 307-309. https://doi.org/10.1016/i.pisc.2016.04.061

[14] Pasandín, A.R.; Pérez, I.; Ramírez, A.; Cano, M.M. 2016: Moisture damage resistance of hot-mix asphalt made with paper industry wastes as filler, Journal of Cleaner Production, 112 (Part 1), pp. 853-862. https://doi.org/10.1016/i.jclepro.2015.06.016

Khliefat, I, Msallam, M 
[15] Likitlersuang, S.; Chompoorat, T. 2016: Laboratory investigation of the performances of cement and fly ash modified asphalt concrete mixtures, International Journal of Pavement Research and Technology, 9 (5), pp. 337-344. https://doi.org/10.1016/j.ijprt.2016.08.002

[16] Asphalt Institute Manual Series (MS-2). 1993: Marshall Methods for Asphalt concrete and hot mix types, Lexington $\mathrm{KY}$.

[17] Tunnicliff D.G. 1962: A Review of Mineral Filler. A.A.P.T, 3.

Please cite this article as: Khliefat, l.; Msallam, M.: Modification of asphalt mixes using white cement dust and iron filings as a filler, Electronic Journal of the Faculty of Civil Engineering Osijek-e-GFOS, 2020, 21, pp. 67-77, https://doi.org/10.13167/2020.21.6 